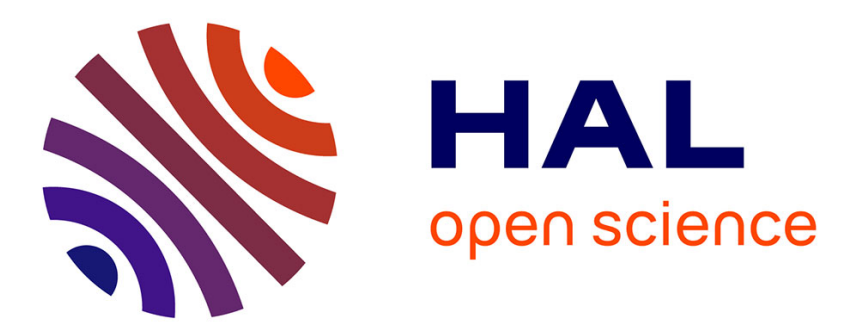

\title{
Sympatric Invasive Rats Show Different Diets in a Tropical Rainforest of an Island Biodiversity Hotspot1
}

Quiterie Duron, Edouard Bourguet, Martin Thibault, Sarah Scussel, Raphaël Gouyet, Mathilde Méheut, Eric Vidal

\section{- To cite this version:}

Quiterie Duron, Edouard Bourguet, Martin Thibault, Sarah Scussel, Raphaël Gouyet, et al.. Sympatric Invasive Rats Show Different Diets in a Tropical Rainforest of an Island Biodiversity Hotspot1. Pacific Science, 2019, 73 (2), pp.199. 10.2984/73.2.2 . hal-02491333

\section{HAL Id: hal-02491333 https://hal.science/hal-02491333}

Submitted on 26 Feb 2020

HAL is a multi-disciplinary open access archive for the deposit and dissemination of scientific research documents, whether they are published or not. The documents may come from teaching and research institutions in France or abroad, or from public or private research centers.
L'archive ouverte pluridisciplinaire HAL, est destinée au dépôt et à la diffusion de documents scientifiques de niveau recherche, publiés ou non, émanant des établissements d'enseignement et de recherche français ou étrangers, des laboratoires publics ou privés. 


\title{
Sympatric Invasive Rats Show Different Diets in a Tropical Rainforest of an Island Biodiversity Hotspot ${ }^{1}$
}

\author{
Duron Quiterie, ${ }^{2,4}$ Bourguet Edouard, ${ }^{2,3}$ Thibault Martin, ${ }^{2,3}$ Scussel Sarah, ${ }^{2}$ \\ Gouyet Raphaël, ${ }^{2}$ Mébeut Matbilde, ${ }^{2}$ and Vidal Eric ${ }^{2}$
}

\begin{abstract}
Invasive rats (Rattus rattus, $R$. norvegicus, $R$. exulans) are recognized as a major threat to native island ecosystems and biodiversity. On many islands, two or three invasive rat species co-occur, often sharing the same habitat; however few studies have focused on the effects of coexisting invasive rat species on native biodiversity. We investigated rat population ecology and diet in a NewCaledonian rainforest where black (Rattus rattus) and Pacific rats ( $R$. exulans) coexist. Black rats dominated Pacific rats in relative abundance with a proportion varying between 80.9 and $88.9 \%$. A total of 374 black rats and 87 Pacific rats were sampled for diet assessment through stomach and caecum analysis. Rat diet was mainly composed of plants, invertebrates and to a lesser extent Squamata, with black rats being more frugivorous and Pacific rats being more omnivorous. Ten of 15 endemic skink and gecko species were consumed, nine species by black rats and six species by Pacific rats. Thus, the presence of both rat species may strengthen the overall predation rate on each native prey species, and/or broaden the total number of native prey species impacted in the New-Caledonian rainforest. These results highlight the importance of preventing new rat species introduction on islands to avoid the strengthening and/or the broadening of negative effects on native biodiversity, and the importance of following the proportion of each rat species during rat control operations. Research to assess the threats generated by various assortments of rodent species on native biodiversity could improve priority setting in conservation actions.
\end{abstract}

Keywords: rodent impacts, sympatric species diet, food preference, trophic niche partitioning, endemic Squamata, island conservation

ALIEN SPECIES INVASIONS ARE recognized as a main cause of species extinction and ecosystem degradation on islands (Blackburn et al. 2004, Tershy et al. 2015). The overall impact of invasive species on islands increases with invasive species richness and native species endemism (Blackburn et al. 2004, Walsh et al.

${ }^{1}$ This study was funded by the Northern Province of New Caledonia to REFCOR project (Réponses des 2012a). Consequently, island communities facing multiple invasive species may be particularly endangered (Bellard et al. 2014). The presence of multiple invasive predator species can strengthen the overall predation rate on each native prey species, and/or broaden the total number of native prey species impacted

Ecosystèmes Forestiers au COntrôle des Rongeurs, Conventions $\mathrm{n}^{\circ} 12 \mathrm{C} 240,14 \mathrm{C} 330$ and 15C154). Manuscript accepted 20 November 2018.

${ }^{2}$ Aix Marseille Université, CNRS, IRD, Avignon Université, IMBE, Centre IRD de Nouméa - BP A5, 98848 Nouméa Cedex, Nouvelle-Calédonie, France.

${ }^{3}$ IAC (Institut Agronomique néo-Calédonien), Axe 2 Diversités biologique et fonctionnelle des écosystèmes terrestres, BP 73, 98890 Païta, New Caledonia.

${ }^{4}$ Corresponding author (e-mail: kithry@hotmail.fr). 
(Blackburn et al. 2004, 2005). The strengthening and the broadening of invasive predator effects on native prey species caused by multiple invasions seems obvious in the case of invasive predators of very different functional types and with different ecological niches. However, it is still unclear whether phylogenetically closelyrelated invasive species (with potentially quite similar ecological niches and impacts) will show sufficient niche complementarity for the multiple invasion to be functionally different than an invasion by only one of these species (Kumschick et al. 2015).

Several closely-related species of rats (Rattus rattus, $R$. norvegicus, $R$. exulans) are highly invasive and have been introduced on most of the world's island groups (Atkinson 1985, Towns et al. 2006, Russell et al. 2014). Rattus spp., in the order of impact strength: $R$. rattus, $R$. norvegicus and $R$. exulans, are recognized as major threats for native island ecosystems and biodiversity (Towns et al. 2006, Capizzi et al. 2014, Harper and Bunbury 2015). On many islands, two or three species of invasive rats co-occur, sharing generally the same habitats and the same range of resources (Yom-Tov et al. 1999, Russell et al. 2014, 2015). In tropical islands of the Pacific Ocean, successive human settlements have been responsible for several waves of rat introductions. It is assumed that Pacific rats ( $R$. exulans) colonized major island groups during the first Austronesian and Polynesian settlements, from 1500 B.C. to 1000 A.D. (Atkinson 1985, Matisoo-Smith and Robins 2004). More recently, starting from the sixteenth century, black ( $R$. rattus) and/or Norway rats ( $R$. norvegicus) have been brought by European settlers (Atkinson 1985), which has often lead to over-invasion of the islands where Pacific rats were already established (Russell et al. 2014, 2015). Their impacts upon island biodiversity are generally considered to be quite similar (Towns et al. 2006, Jones et al. 2008), but few studies have compared the ecology of sympatric alien rats on islands (Shiels et al. 2013, Russell et al. 2014, 2015), or examined potential differences in their effects on native biodiversity (Jones et al. 2008, St Clair 2011). Although such studies are scarce, they are crucial to evaluate invasive rat effects on biodiversity, and to make evidence-based decisions about rat management (Ringler et al. 2014, Harper et al. 2015).

Trophic relationships between rats and native biodiversity can be revealed through rat diet studies (e.g. Shiels et al. 2013, ZarzosoLacoste et al. 2016). Among 55 studies examined (Supplemental Online Material, Appendix 1), rat diet was highly variable depending on the geographic area and the ecosystem. Most studies (i.e. 36, or $66.7 \%$ ) dealt with one species of rat only, seven studies (13\%) concerned both the Pacific and the black rat, one $(1.9 \%)$ was on both the black and the Norway rat, and only one considered the three rat species together. This observation highlights a need for more research on the impacts of invasive rats coexisting in different assortments. Most of the time, black rats are reported to be almost exclusively herbivorous (Sweetapple and Nugent 2007, Caut et al. 2008, McQueen and Lawrence 2008, Ruffino et al. 2011), although their diet is sometimes dominated by invertebrates (Clout 1980). The dominance of plants or invertebrates can even switch across seasons (Daniel 1973). Age and sex of black rats may also lead to individual diet differences with higher frequency of occurrence of animal remains in juvenile and female stomachs (Gales 1982). Vertebrates, and particularly birds, which are often considered to be highly threatened by invasive rats (Jones et al. 2008, O'Donnell and Hoare 2012), are sparsely represented in the black rat diet (Innes 1979, Harper 2007) except in some coastal areas (Yabe et al. 2009, Rodríguez and Herrera 2013, Ringler et al. 2015). Conversely, Pacific rats are reported to be more omnivorous, with a high consumption of both plants and invertebrates (Bettesworth 1972, Ferreira et al. 2001). When black and Pacific rats coexist, their diets are often reported to be similar (Fall et al. 1971, Robinet et al. 1998, Beard and Pitt 2006). However, Sugihara (1997) and Shiels et al. (2013) suggested a dietary niche differentiation among introduced rodents in Hawaiian forests, with black rats being more herbivorous and Pacific rats being more omnivorous. These results suggest that invasive rats may show both trophic niche 


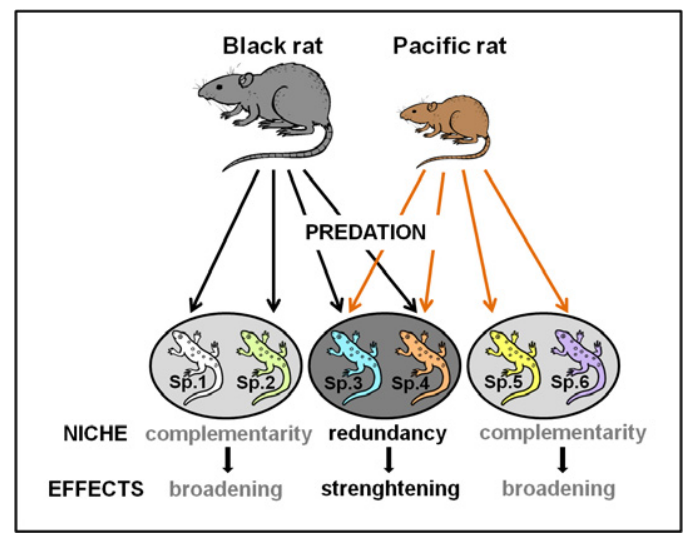

FIGURE 1. Niche complementarity and redundancy for black and Pacific rat respectively induce a broadening and a strengthening of the negative effects on biodiversity. The species 1 (Sp.1) and the Sp.2 are only preyed upon by Black rats whereas the Sp.5 and the Sp.6 are only preyed upon by Pacific rats when both rat species coexist. Black rat and Pacific rat niches are complementary and more prey species can be affected. Conversely, Sp. 3 and Sp. 4 are concurrently preyed upon by both rat species: rat niches are redundant and effects observed on these species can be stronger.

redundancy and complementarity (Figure 1). Consequently, they may have different effects on native biodiversity, and the arrival of another rat species may both strengthen and broaden the overall rat effects on biodiversity (Figure 1).

A better knowledge of the ecology of invasive rat communities is needed in order to understand the need for and implications of management operations in sensitive areas such as biodiversity hotspots. The New Caledonia archipelago (South Pacific) is one of the world's 36 biodiversity hotspots (Myers et al. 2000, Mittermeier et al. 2011, Critical Ecosystem Partnership Fund 2017), with exceptional endemism rates for fauna and flora (e.g. endemism rates of rainforest flora: 83.2\% (Morat et al. 2012); Squamata 92\% (Bauer and Jackman 2006); and cicadas 100\% (Delorme et al. 2016)). Rodents were absent from New Caledonia prior to human arrival 3,000 years ago, but now two invasive rat species, the Pacific rat (which arrived with first human settlers) and the black rat (which arrived with Europeans settlers around
150 years ago), coexist throughout the natural areas of New Caledonia (Beauvais et al. 2006).

In this context, the aim of this work was to explore the respective trophic niches of black and Pacific rats, and to use this information along with population demographic data for each species to predict their respective effects on native biodiversity in a New Caledonian rainforest. This was done by assessing rat diet and by measuring rat community parameters and individual characteristics. Specifically, we addressed the following questions: (i) What are the relative abundances, weights, sex ratios, and proportions of juveniles of black and Pacific rats in our study area? (ii) How do the identities and proportions of organisms consumed by black and Pacific rats differ? (iii) How does rat diet change with age, sex, and capture sessions for each species? and, (iv) Integrating this information with the conservation statuses of local endemic species, what can we predict about the respective and combined effects of invasive rats on native flora and fauna in New Caledonian rainforest, and what recommendations can we therefore make for rat population management?

\section{MATERIALS AND METHODS}

\section{Study Site}

This study was conducted in a dense evergreen rainforest located between 550 and $950 \mathrm{~m}$ a.s.l. in the wilderness reserve of Mont Panié ( $\left.20^{\circ} 37^{\prime} 30^{\prime \prime} \mathrm{S}, 164^{\circ} 46^{\prime} 56^{\prime \prime} \mathrm{E}, 5400 \mathrm{ha}\right)$ in the northern province of New Caledonia (Figure $2 A-C$ ). Mont Panié reserve has been protected since 1950 because of its cultural importance and high micro-endemism rates observed for most taxa (plants, insects, Squamata) (Tron et al. 2013). The climate is moist subtropical with a hot season between December and mid-April and a cool season between mid-May and September. The area is mainly covered by primary rainforest lying on a metamorphic substrate. In 2010, a rapid assessment survey evaluated the fauna and flora biodiversity of the Mont Panié region, listing 617 species of plants, 29 of birds, 18 of 


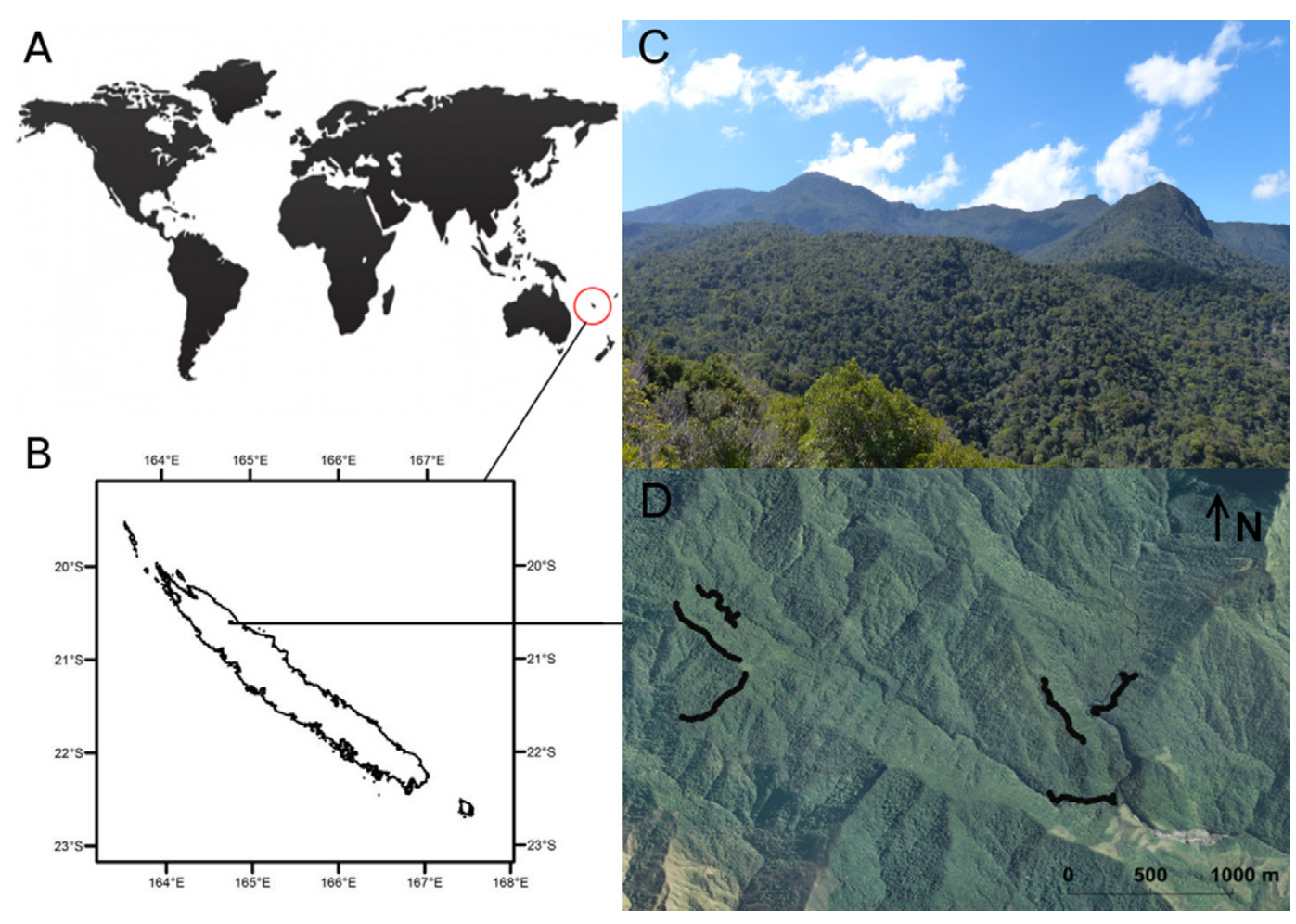

Figure 2. Location of the study in the wilderness reserve of Mont Panié, northern New Caledonia. $(A)$ Location in the world. $(B)$ Location in New Caledonia. $(C)$ Mountain rainforest of Mont Panié. $(D)$ Location of the 6 rat transects (black lines) in Mont Panié study area.

Squamata, 19 of freshwater fishes and crustaceans, and 23 odonates (Tron et al. 2013).

\section{Rat Sampling}

In order to determine rat population parameters and to collect individuals for the diet analysis, we worked on six line-transects of $600 \mathrm{~m}$ length (Figure 2D). Thirty traps were set up along each transect, spaced by $20 \mathrm{~m}$. Rats were caught at each site using the "Snap E Rat Trap" (Kness Mfg. Co., Albia, IA, USA). Four capture sessions of five consecutive nights took place in April-May 2013 (end of hot season), November-December 2013 (hot season), September 2014 (end of cool season) and April 2015 (end of hot season). Each day, traps were baited with coconut chunks at sunset and checked at sunrise. All rats caught were identified to species level (black rat $R$. rattus versus Pacific rat
$R$. exulans), sexed, weighed to the nearest $2.5 \mathrm{~g}$, and checked for sexual maturity (females: perforate vagina and teat development status, males: presence of a scrotal sac). Because most black rat individuals weighing more than $120 \mathrm{~g}$ and most of Pacific rat individuals weighing more than $55 \mathrm{~g}$ were sexually mature (respectively $95 \%$ and $96 \%$ ), we used the weight as a proxy of rat sexual maturity.

\section{Rat Community and Population Parameters}

In order to compare relative abundances of the two rat species across seasons and years, we calculated an index of abundance (IA) as the number of trapped rats per 100 trap-nights, adjusted for the corrected number of trapnights $(\mathrm{CTN})$, that is, by subtracting half a trap night for each sprung trap (Nelson and Clark 1973). IA were estimated for each transect on 
each night of trapping and these were used for calculating mean IA and IA standard deviation $( \pm \mathrm{SD})$. To test whether the number of trapped rats changed between capture sessions for all rats or for each species separately, we used three binomial Generalized Linear Models (GLMs). The proportions of total rats, black rats, and Pacific rats trapped on the total number of traps available for each transect on each night of trapping were respectively the three response variables. In each model, 'capture session' was the predictor variable, and we used a chi-square test to assess the significance of the deviance change between the null model and the model with the variable (Note that the variable 'capture session' encompasses tests of both the effects of season and year, since the first two capture sessions were different seasons within one year, the third capture session was a different season again, but also a different year, and the fourth capture session repeated the April capture session in a different year.). Then, to test whether the proportion of trapped Pacific rats may vary with trapped black rats, we used a binomial GLM model with 'proportion of Pacific rats' as the response variable and 'number of black rats' as the predictor variable. Finally, to test whether sex-ratio or proportion of juveniles changed with capture session for each rat species, we used four GLM models. In models for each species separately, either 'sexratio' or 'proportion of juveniles' was the response variable and 'capture session' was the predictor variable. All analyses were conducted with R 2.15.3.

\section{Rat Diet Analysis}

Stomachs and caeca of trapped rats were collected and preserved in 95\% ethanol (Clark 1982). For both rat species, diets were assessed by morphological analysis of food items from stomach and caecum contents. Although the majority of diet studies are based on stomach contents alone (Sugihara 1997, Shiels et al. 2013), a recent study has shown that combined analysis of stomach and caecum contents provides much more information on taxon richness in rat diet, particularly for Squamata (Thibault et al. 2017). Each sample, that is, stomach or caecum, was rinsed with tap water and sieved through a $500 \mu \mathrm{m}$ mesh (Sugihara 1997). Macroremains from each sample were placed in a Petri dish, examined and identified under a dissecting microscope (10-40× magnification). Each item was identified to the lowest taxonomic level possible using a reference collection. A determination key based on morphology of scales was used to determine skink remains to species level (IMBE, unpublished data). Frequency of occurrence (percent) for each food item and each food type (plants, invertebrates, Squamata, birds) was determined by dividing the number of samples (i.e. rat individuals) containing the food item or food type by the total number of analyzed samples. Based on the volume occupied by remains in the Petri dish (Sugihara 1997), a score ranging from 0 to 5 was given for each food type (plants, invertebrates, Squamata, and birds) as follows: 0 (absent), 1 (<0.5\%), 2(>0.5 to $5 \%)$, 3 (>5 to $25 \%$ ), 4 (>25 to $50 \%$ ), and 5 (>50\%).

Due to an estimated mean transit time of $12 \mathrm{~h}$ in rats (Platel and Srinivasan 2001), stomach contents include consumed items for only a few food intakes. By contrast, the caecum can stock remains that are difficult to digest from multiple food intakes (Perrin and Curtis 1980). For example, items with cellulose (e.g. plant seeds), chitin (e.g. insect cuticle) or keratin (e.g. Squamata scales, bird feathers) need a longer time to be digested than fruit pulp or animal flesh, and may be retained during several food intakes. Consequently, stomach contents may better reflect the relative proportions of consumed items than caecum contents. Therefore, we chose to estimate frequencies of occurrence and volume scores based on stomach contents data only. By contrast, we used both stomach and caecum data in order to get the maximum resolution on Squamata diversity in rat diet (Thibault et al. 2017).

First, to test whether the frequency of occurrence for each food type changed with rat species, we used four binomial GLMs, with 'plant frequency of occurrence (FO)', 'invertebrate FO', 'Squamata FO', or 'bird FO' as the response variables. In each model, 'rat species' was the predictor variable, and we used chi-square tests to assess the significance 
of the deviance change between the null model and the model with the 'rat species' variable. Next, for each species considered independently, we checked whether the frequency of occurrence (FO) for each food type varied with sex, age, or capture session using binomial GLMs. In each model, 'plant FO', 'invertebrates FO', 'Squamata FO' or 'bird FO' were the response variables and 'sex', 'age', or 'capture session' were the predictor variables. We also used chi-square tests to assess the significance of the deviance change between the null model and the models with 'sex', 'age', or 'capture session' variables.

Second, the effect of rat species on relative volume scores of each food type were assessed with a PERMANOVA, that is permutational multivariate analysis of variance for non parametric data (Anderson 2001). The PERMANOVA test uses the distances between samples to partition variance, and uses randomizations or permutations of the data to produce the p-value for the hypothesis test. As volume scores corresponded to categories with unequal class intervals, distances between each individual were calculated with Gower's method which considers non-numeric ordinal data (Gower 1971). The number of permutations was set at 999 . The distance matrix of relative volume scores of each food type was used as the response variable and 'rat species' as the predictor variable. We also ran PERMANOVA for each rat species to assess if relative volume scores changed with sex, age and capture session. The distance matrix of relative volume scores was used as the response variable and 'sex', 'age' or 'capture session' were the predictor variables. For the four levels of the 'capture session' variable, we performed post-hoc tests, that is, pairwise comparisons for PERMANOVA.

Last, we described in detail the diets of black rats and Pacific rats, according to stomach contents, and focused on endemic Squamata species which were found either or both in stomachs and caeca. All the analyses described above were performed with the $\mathrm{R}$ packages 'vegan' (Oksanen et al. 2016), 'cluster' (Maechler et al. 2016) and 'ade4' (Dray et al. 2016) in the $\mathrm{R}$ version 2.15.3.

\section{RESULTS}

\section{Rat Community and Population Parameters}

Mean rat IA ranged between $8.33 \pm 9.21$ $( \pm$ SD, September 2014) and $46.83 \pm 16.17$ $( \pm$ SD, April 2015) per 100 corrected trapnights (100 CTN). The mean IA for black rats was $20.02 \pm 11.37$ and mean IA for Pacific rats was $3.19 \pm 3.42$ per $100 \mathrm{CTN}$ (Figure 3 ). The chi-square test conducted in the GLM results showed the existence of a significant effect of capture session on the total number of trapped rats (deviance explained by the variable (dev) $=46.49 \%, P<.001$, Figure 3$)$. The number of black rat captures varied with capture session $(\mathrm{dev}=44.68 \%, P<.001)$ as did the number of Pacific rat captures $(\mathrm{dev}=15.51 \%, P<.001$, Figure 3). Although we did not statistically test year and season effects separately, the capture session effect seems to be due to strong changes in abundance between years, rather than between seasons (Figure 3). For black rat, IA in April 2015 was three times higher than at approximately the same period in April-May 2013. For Pacific rat, IA in April 2015 was two times higher than in AprilMay 2013 (Figure 3). Black rats were consistently more often trapped than Pacific rats (Figure 3), with a proportion varying between 80.88 and $88.89 \%$ according to the capture session. The proportion of Pacific rats decreased with black rat relative abundance

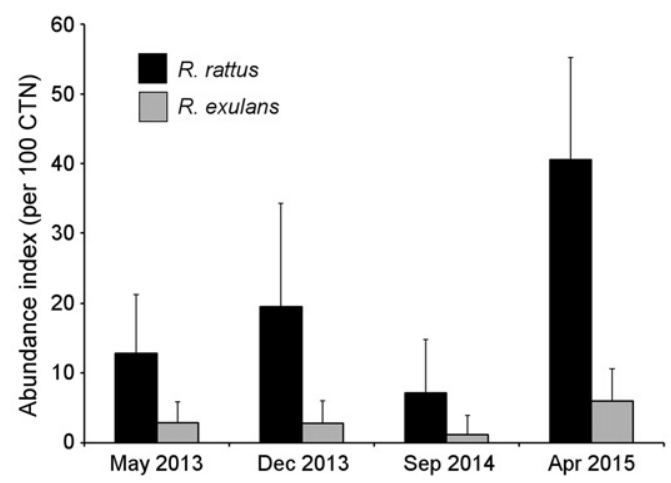

Figure 3. Mean $( \pm$ SD) of index of abundance (per $100 \mathrm{CTN})$ for black rat ( $R$. rattus) and Pacific rat ( $R$. exulans) recorded during the first five days of trapping by snap trapping line captures in Mont Panié study area. 
$(\mathrm{dev}=8.84 \%, P=.007)$ but did not vary with capture session $(\mathrm{dev}=2.24 \%, P=.601)$.

Sex-ratio varied, but was not significantly different between rat species ( $\operatorname{dev}=0.2 \%$, $P=.473)$ nor between capture sessions (dev $=1.76 \%, P=.246$ ) (Supplemental Online Material, Appendix S2). The proportion of juveniles in the population did not vary with species (dev $=0.17 \%, P=.772$, Supplemental Online Material, Appendix 2). However, the proportion of juveniles changed significantly across capture sessions $(\mathrm{dev}=53.9 \%, P<.001$, Supplemental Online Material, Appendix 2). In September 2014, the proportion of juveniles was very low and significantly lower than in May $2013(P=.011)$, December 2013 $(P<.001)$ and April $2015(P=.007)$. The highest proportion of juveniles was recorded in December 2013: 42.3\% for the black rat and $65 \%$ for the Pacific rat (Supplemental Online Material, Appendix 2).

The mean black adult rat weight was $177.40 \pm 30.09 \mathrm{~g}( \pm \mathrm{SD})$ and the mean Pacific adult rat weight was $71.58 \pm 11.77 \mathrm{~g}$ $( \pm \mathrm{SD})$.

\section{Rat Diet}

Rat stomachs and caeca were collected during each capture session (April-May 2013: $n=112$; November-December 2013: $n=150$; September 2014: $n=68$; and April 2015: $n=131$ ) for a total of 374 black rat and 87 Pacific rat samples (Supplemental Online Material, Appendix 3). We found rat diet in Mont Panié forest to be mainly composed of plants and invertebrates (Figure $4 a$ ). For plants, the frequency of occurrence (FO) was higher in black rat stomachs than in those of Pacific rats (deviance explained by the model (dev): $21.41 \%, P<.001)$. Conversely, Pacific rat stomachs contained invertebrates significantly more frequently than those of black rats (dev: $25.17 \%, P<.001)$. We did not find differences for the FO of Squamata or bird remains among the two rat species (respectively dev: $2.61 \%, P=.106$ and dev: $1.68 \%, P=.195$ ). Nonetheless, $9.20 \%$ of Pacific rat stomachs and $4.55 \%$ of black rat stomachs contained Squamata remains. No bird remains were found in Pacific rat stomachs and only $1.07 \%$
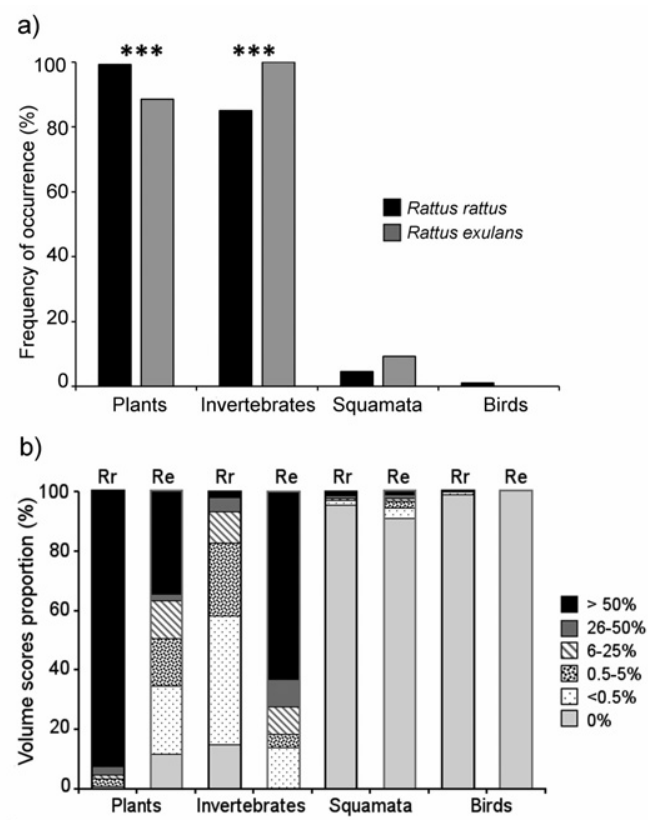

FigURE 4. (a) Frequency of occurrence and (b) volume scores proportion for major prey groups found in black rat (R. rattus) and Pacific rat (R. exulans) stomachs. The number of * indicates the degree of significance $\left.{ }^{*} P<.05,{ }^{* *} P<.01,{ }^{* * *} P<.001\right) . \mathrm{Rr}$ : $R$. rattus and Re: $R$. exulans.

of black rat stomachs contained bird feathers (Figure $4 a$ ).

For each rat species, we examined if the FO for each food type varied with sex, age, or capture session. For black rats, we found that plant, invertebrate, and bird FO did not vary with sex, age, or capture session. However, Squamata FO varied with age $(\mathrm{dev}=4.52 \%, P=.012)$ and capture session $(\mathrm{dev}=12.48 \%, P<.001)$. Squamata remains were more often present in stomachs from juvenile than from adult individuals. The rate of stomachs with Squamata remains was the highest for April 2015 sampling compared with all other sessions.

For the Pacific rat, we found that plant FO varied with capture session ( $\mathrm{dev}=17.91 \%$, $P=.01)$. We observed significantly more plants in stomachs collected in May 2013 and December 2013 compared to September 2014 (respectively $P=.018$ and $P=.007$ ). Invertebrate FO and Squamata FO did not 
show any significant variation according to sex, age, or capture session.

Relative volumes of the different item categories were significantly different according to rat species $\left(R^{2}=39, P=.001\right.$, Figure $4 b$, Supplemental Online Material, Appendix 4). Black rats ate a higher volume of plants whereas Pacific rat ate more invertebrates (Figure 4b). For the black rat, the relative volumes did not vary significantly with age $\left(R^{2}=0.45, P=.228\right)$, or sex $\left(R^{2}=0.01, P=.828\right)$ but did vary significantly with capture session $\left(R^{2}=6.04\right.$, $P=.001)$. Post-hoc tests revealed that the relative volume of insects and Squamata in black rat stomachs were significantly higher in September 2014 and April 2015 than in AprilMay and December 2013. For the Pacific rat, the relative volumes did not vary with age $\left(R^{2}=1.11, P=.358\right)$ or $\operatorname{sex}\left(R^{2}=3.57, P=.067\right)$, nor with capture session $\left(R^{2}=7.85, P=.058\right)$.

Regarding plant material, we found that $35.0 \%$ of black rat stomachs contained seeds and $96.8 \%$ contained fruit pulp (Table 1). However, plant remains in stomachs were difficult to identify at high taxonomic resolution. Regarding seeds, we were able to identify seeds of Freycinetia sulcata and Ficus spp. For the Pacific rat, $27.6 \%$ of stomachs contained seeds and $77.0 \%$ contained fruit pulps. The invertebrates found were Arachnida, Chilopoda, Crustaceae, Insecta, Gastropoda and Oligochaeta. Pacific rats ate more Arachnida, Chilopoda, Crustaceae, Coleoptera (Carabidae and Curculionidae), Orthoptera, Dictyoptera, Lepidoptera larvae, Gastropoda and Oligochaeta than black rats. By contrast, black rats ate more Formicidae than Pacific rats.

Squamata identifications were conducted for remains from both stomach and caecum contents. Studying both organs provided more scale remains and information about Squamata species preyed upon by rats (Tables 1 and 2). The frequency of occurrence of Squamata in black rat stomachs was $4.55 \%$, compared to $6.17 \%$ in both stomachs and caeca, and $9.20 \%$ compared to $23.26 \%$ for Pacific rats (Table 2). Regarding prey diversity, black rats preyed upon more species than Pacific rats, with seven species of diurnal skinks (Scincidae) and two species of geckos (Diplodactylidae). Conversely, Pacific rats preyed upon six species of diurnal skinks, mostly Celatiscincus similis and Caledoniscincus aquilonius (Table 2). Among the 15 Squamata species present at the Mont Panié study site, our sampling detected 10 species eaten by rats. Among these species, five were eaten by both rat species, and five were eaten by one rat species only. Concerning birds, only five black rat stomachs contained bird remains, and of these, only feathers of the native Coconut Lorikeet Trichoglossus baematodus in one stomach were identifiable.

\section{DISCUSSION}

Black and Pacific rats have coexisted for more than a century in New-Caledonian rainforests (Beauvais et al. 2006). In our study, black rats were considerably more frequently trapped than Pacific rats and both rat species were omnivorous, eating mainly plants, invertebrates and to a lesser extent, Squamata. However, frequencies of occurrence of each food type were different depending on the rat species: black rats were more frugivorous whereas Pacific rats were more omnivorous, eating a greater proportion of invertebrates and Squamata. Some prey taxa were preyed upon by both black and Pacific rats, whereas other taxa were preyed upon by one rat species only. These results seem to show that black and Pacific rat trophic niches are both partially redundant and complementary when coexisting. However, the fact that the sample of black rats is larger than that of Pacific rats may have partially influenced the width of the trophic niche found. Rat relative abundance fluctuated across sessions, and demographic parameters (sex-ratio and proportion of juveniles) fluctuated across sessions. In our study, relative volume of each food type changed with maturity as well as sessions for black rats. Therefore invasive rat diet and overall effects on biodiversity may also vary greatly along with seasons and years, and relative abundances of plants and animals available (Caut et al. 2008, Ruffino et al. 2011).

The magnitude of a rat populations' effects on native species may depend on the abundance and population structure of each rat species. In our study site, the rat relative abundance seems high for tropical island 
Diet of Sympatric Invasive Rats on Islands - Duron et al.

TABLE 1

Frequency of Occurrence (\%) for Plants, Invertebrates, Squamata and Bird Taxa Identified in Black Rat and Pacific Rat Stomach Contents

\begin{tabular}{|c|c|c|c|c|}
\hline Group & Order/Family & Species or Taxa Identified & $\begin{array}{c}\text { Black Rat } \\
(n=374)\end{array}$ & $\begin{array}{c}\text { Pacific Rat } \\
(n=87)\end{array}$ \\
\hline PLANTS & & & 99.20 & 88.50 \\
\hline \multirow[t]{4}{*}{ Seeds } & & & 35.29 & 27.59 \\
\hline & Pandanaceae & Freycinetia sulcata & 14.97 & 2.3 \\
\hline & Moraceae & Ficus spp & 1.34 & 0.00 \\
\hline & undefined seeds & & 23.8 & 25.29 \\
\hline Fruit pulp & & & 96.79 & 77.01 \\
\hline Other plant material & & & 32.62 & 32.18 \\
\hline INVERTEBRATES & & & 85.00 & 100.00 \\
\hline \multirow[t]{3}{*}{ Arachnida } & & & 14.17 & 45.98 \\
\hline & Araneae & & 13.64 & 45.98 \\
\hline & Opiliones & & 2.06 & 0.00 \\
\hline Chilopoda & & & 7.49 & 62.07 \\
\hline Crustaceae & & Amphipods and isopods & 0.00 & 5.88 \\
\hline \multirow[t]{12}{*}{ Insecta } & & & 81.82 & 97.7 \\
\hline & Coleoptera Scarabidae & & 5.88 & 16.09 \\
\hline & Coleoptera Curculionidae & & 0.27 & 5.75 \\
\hline & Coleoptera others & $\begin{array}{l}\text { Cucujoidae, Staphilinidae } \\
\text { and undefined species }\end{array}$ & 17.65 & 20.69 \\
\hline & Blattodea & Cockroaches & 7.75 & 28.74 \\
\hline & Hymenoptera Formicidae & $\begin{array}{l}\text { mainly Paraparatrechina sp } \\
\text { and Pheidole sp }\end{array}$ & 25.4 & 10.34 \\
\hline & Hymenoptera others & & 5.08 & 3.45 \\
\hline & Orthoptera & Crickets, grasshoppers, wetas & 12.03 & 26.44 \\
\hline & Phasmatodea & Stick insects & 8.06 & 12.64 \\
\hline & Imago others & $\begin{array}{l}\text { Dermaptera, Thysanoptera, Diptera, } \\
\text { Hemiptera and undefined imago }\end{array}$ & 43.85 & 41.38 \\
\hline & Larvae Lepidoptera & Caterpillars & 17.11 & 59.77 \\
\hline & Larvae others & $\begin{array}{l}\text { Coleoptera, Diptera, Hemiptera } \\
\text { and undefined larvae }\end{array}$ & 5.88 & 24.14 \\
\hline Gastropoda & Pulmonata & Snails and slugs & 2.14 & 24.14 \\
\hline Annelida & Oligochaeta & Earthworms & 2.41 & 18.39 \\
\hline REPTILES & & & 4.55 & 9.20 \\
\hline \multirow[t]{2}{*}{ Squamata } & Scincidae & species specified in Table 2 & 2.94 & 11.49 \\
\hline & Diplodactylidae & species specified in Table 2 & 1.6 & 0.00 \\
\hline BIRDS & & & 1.07 & 0.00 \\
\hline \multirow[t]{2}{*}{ Psittaciformes } & Psittacidae & Trichoglossus baematodus deplancheii & 0.27 & 0.00 \\
\hline & undefined birds & & 1.07 & 0.00 \\
\hline
\end{tabular}

rainforests, compared with other studies (but note that the calculation of rat relative abundances depends on trap type and spacing). In Hawaii, an IA of roughly 8-17 per
$100 \mathrm{CTN}$ was recorded in wet forests on Maui (Sugihara 1997) and of roughly 11-25 per 100 CTN in wet forests on Big Island (Lindsey et al. 1999). For our sampling site, mean black 
TABLE 2

List of Squamata Observed in Mont Panié Rainforest and Their Frequency of Occurrence (\%) in Black Rat and Pacific Rat Stomach and Caecum Contents

\begin{tabular}{lllcc}
\hline \hline & & \multicolumn{2}{c}{ Frequency of Occurrence (\%) in Stomachs and Caeca } \\
\cline { 4 - 5 } & Binomen & IUCN Status & Black Rat & Pacific Rat \\
\hline Scincidae & Caledoniscincus aquilonius & NT & 0.00 & 4.65 \\
& Caledoniscincus festivus & LC & 0.54 & 0.00 \\
& Caledoniscincus baplorbinus & LC & 0.54 & 1.16 \\
& Caledoniscincus orestes & EN & 0.00 & 0.00 \\
& Epibator nigrofasciolatum & LC & 0.54 & 1.16 \\
& Caesoris novaecaledoniae & LC & 0.27 & 1.16 \\
& Lioscincus steindachneiri & EN & 0.00 & 0.00 \\
& Celatiscincus similis & EN & 1.34 & 2.33 \\
& Marmorosphax tricolor & LC & 1.07 & 0.00 \\
& Tropidoscincus boreus & LC & 0.27 & 5.81 \\
& Undefined scales & & 0.27 & 0.00 \\
Bavayia montana & DD & 0.54 & data \\
Bavayia sauvagii & DD & no data & 0.00 \\
Eurydactylodes agricolae & NT & 0.80 & 0.00 \\
Saniegekko madjo & NT & 0.00 & 0.00
\end{tabular}

Squamata* corresponds to the total frequency of occurrence (\%) of Squamata remains in black rat and Pacific rat stomach and caecum contents. IUCN categories: NT (Near Threatened), LC (Least Concern), EN (Endangered), DD (Data Deficient).

rat IA was around 20.0 per $100 \mathrm{CTN}$ and mean Pacific rat IA was around 3.2 per 100 CTN. Shiels et al. (2013) also highlighted the dominance in abundance of black rats over Pacific rats in Hawaii; data from capturemark-recapture gave IA of 13.5 for black rats and of 0.7 for Pacific rat. This result can come from a lower true abundance of Pacific rats, but may also reflect a lower attractiveness for the bait used (coconut flesh) or even a lower tendency of Pacific rats to explore novel objects. In our case, the proportion of Pacific rats decreased with black rat abundance suggesting that Pacific rats might be less competitive at accessing traps than the larger black rats (Harper and Veitch 2006). Black rats weighed around $149 \mathrm{~g}$ and Pacific rats around $61 \mathrm{~g}$ which are very close to weights found in other tropical forests, for example, by Sugihara (1997) and Rouys (2008). As rats consume about $10 \%$ of their weight each day
(Long 2003), a black rat may eat more than $5 \mathrm{~kg}$ of food each year where as a Pacific rat may eat around $2 \mathrm{~kg}$ of food. However, even if Pacific rats may be present in lower abundance and are smaller than black rats, their presence likely strengthens the overall rat impact on shared prey species, and broadens the rat overall impact by extending the number of native species impacted.

Our results also suggest that the overall effects of invasive rats in Mont Panié study site are likely high for plants, invertebrates and Squamata. Regarding the high proportion of plant remains in rat diets and the occurrence of fragmented or intact seeds, black rats especially may contribute negatively (as seed destructors) or positively (as seed dispersers) to plant reproduction and dynamics (Williams et al. 2000, Meyer and Butaud 2008, Shiels and Drake 2011, Pender et al. 2013). Precise identification of consumed plants was almost 
impossible without molecular analysis as fruit and seed remains were highly fragmented. Among intact seeds, Freycinetia sulcata and Ficus spp. were the only seeds identified in stomach contents, and are likely part of the set of plant species dispersed by rats (Duron et al. 2017b). Unfortunately, we could not identify other seeds destroyed by rats and so plant species potentially threatened by rats.

All the Pacific rats and $85 \%$ of black rat samples contained invertebrate remains. However, the predominant invertebrate prey taxa were different according to rat species. Black rats consumed far fewer invertebrates in general but many Hymenoptera, which may be ingested accidentally while eating fruits. In his review, St Clair (2011) reported that beetles (Coleoptera), Orthoptera, and terrestrial mollusks were the taxa most threatened by invasive rats. Macro-insects like stick insects (Phasmatodea) and wetas (Orthoptera) were present in low abundance in rat stomachs. However, these large-bodied insects with little defensive behavior may also be highly threatened by rats (Gibbs 1998, Carlile et al. 2009, Watts et al. 2011) and some uncommon species may have already disappeared from Mont Panié rainforest.

Valuable information on the identity of the Squamata species potentially threatened by rats was provided in this study by the concurrent analysis of stomach and caecum contents. Mont Panié rainforest hosts at least 15 Squamata species (all endemic), 10 species of skinks and five species of geckos (Tron et al. 2013). Among these species, five were preyed upon by both rat species and five by one rat species only, indicating that the presence of both rat species likely strengthens and broadens the overall impacts on Squamata species. The black rat does not seem to be specialized and may eat Squamata opportunistically whereas Pacific rats seemed to prey preferentially on Celatiscincus similis and Caledoniscincus aquilonius, two species evaluated as endangered (EN) and near threatened (NT) respectively under IUCN Red List criteria (IUCN 2016). In this context, invasive rat management may help to reduce threats to endemic Squamata species. On islands of New Zealand, the abundances of skinks and geckos have already shown large increases after rat eradication (Towns and Broome 2003, Monks et al. 2014). At Mont Panié, rat predation rates on Squamata seem relatively high when compared with studies conducted in other tropical forest ecosystems. For example, in two Hawaiian forests (Sugihara 1997, Shiels et al. 2013), no skink or gecko remains were found in black or Pacific rat stomachs. The high incidence of Squamata in our results may also be due to exceptional Squamata fauna richness and abundance in New Caledonia (Bauer and Sadlier 2000).

Despite intensive sampling, we found no evidence that birds or bird eggs are part of Pacific rat diet, and birds only represented a minute part of the black rat diet. Moreover, the possibility that black rats fed in bird carrion instead of live birds cannot be discarded (Zarzoso-Lacoste et al. 2016). Eggs and birds have previously been found to be absent from rat stomach contents in other forests where plants and invertebrates appeared to be their primary food sources (Sugihara 1997, Shiels et al. 2013). Artificial nest experiments conducted in Mont Panié rainforest also suggested a low level of predation on bird eggs but this complements the predation pressure exerted by native predators in this ecosystem (Duron et al. 2017a). However, the few bird remains found in the black rat diet might also be due to the low power of detection of egg predation by diet morphological studies (Zarzoso-Lacoste et al. 2016) and also the rather low abundance of birds in the study area.

Although the management of invasive species in New Caledonia is of primary importance in order to preserve its native and endemic biodiversity (Beauvais et al, 2006, Pascal et al. 2008), very few studies have been conducted on New Caledonia's rat population ecology and diet (Robinet et al. 1998, Rouys 2008, Brescia 2011, Thibault et al. 2017). Our study shows that both Rattus spp. play important and different roles in the overall invasive pressures that native island flora and fauna have to cope with. Our results further suggest that secondary invasion by the black rat where the Pacific rat has already been introduced before is likely to result in a 
strengthening and broadening of overall rat impacts on native biodiversity. Therefore, preventing new rat species introduction on islands, even if one of them is already present, is a crucial conservation goal to avoid new and enhanced risks for native species (Blackburn et al. 2004, Russell et al. 2008, Walsh et al. 2012b, Simberloff et al. 2013). In the absence of competitors, rats are known to have a wider fundamental niche while in presence of competitors, their realized niche is likely to be much narrower. This was already suggested by the change in relative abundances in favor of the dominant rat species (Harper et al. 2005). Further investigation will determine whether in addition to the above, rat diet is modified according to the absence or presence of congeneric rats.

As many invasive rat control operations (i.e. local reduction of rat abundance) are now being conducted on large islands where eradication is not feasible (Duron et al. 2017 c), it is important to ensure, when both rat species are concurrently present, that reduction of Pacific rat abundance operates in parallel with the reduction of the black rat. For instance, their relative abundance can be monitored by trapping transects before, during and after rat control operations. When both species are present in the same habitat, Pacific rat density may be constrained by the dominance of the black rat (Yom-Tov et al. 1999, Russell and Clout 2004). Consequently, a reduction of black rat abundance during rat control may lead to competitor release effects (Caut et al. 2007), which could result in an increase of Pacific rat abundance and Pacific rat effects on threatened endemic invertebrates and Squamata. Invasive rat community impacts on island native biodiversity certainly depend on the assortment of rodent species present, which may include two, three or four species ( $R$. norvegicus, $R$. rattus, $R$. exulans, and $M$. musculus). The effects of invasive rodent assortments in various habitats are little known, and thus there is a great necessity for research to assess threats generated by various rodent assortments on native island biodiversity, in order to define action priorities for biodiversity conservation and restoration.

\section{ACKNOWLEDGEMENTS}

We are grateful to Fabien Leprieur, Pedro Martinez Arbizu and Alexandre Millon, who provided advice in statistical analyses. We also thank Josepho Bahormal, Benjamin Camier, and Frédéric Rigault for their help in the fieldwork, the team of Dayu Biik NGO for logistical assistance in the field, and Hervé Jourdan for his help in diet remains identification. We are also grateful for English advice and useful comments on the paper draft provided by Carol Frost and by two anonymous reviewers.

\section{Literature Cited}

Anderson, M. J. 2001. A new method for nonparametric multivariate analysis of variance. Austral. Ecol. 26:32-46.

Atkinson, I. A. E. 1985. The spread of commensal species of Rattus to oceanic islands and their effects on avifaunas. ICPB Tech Publ. 3:35-38.

Bauer, A. M., and T. Jackman. 2006. Phylogeny and microendemism of the New Caledonian lizard fauna. Pages 9-13 in Proceedings of the 13th Congress of the Societas Europaea Herpetologica.

Bauer, A. M., and R. A. Sadlier. 2000. The herpetofauna of New Caledonia, Society for the Study of Amphibians and Reptiles, in cooperation with the Institut de Recherche pour le Développement.

Beard, K. H., and W. C. Pitt. 2006. Potential predators of an invasive frog (Eleutherodactylus coqui) in Hawaiian forests. J. Trop. Ecol. 22:345-347. doi: 10.1017/S0266467 406003154.

Beauvais, M.-L., A. Coléno, and H. Jourdan, eds. 2006. Invasive species in the New Caledonian archipelago. IRD, Paris.

Bellard, C., C. Leclerc, B. Leroy, M. Bakkenes, S. Veloz, W. Thuiller, and F. Courchamp. 2014. Vulnerability of biodiversity hotspots to global change: Biodiversity hotspots and global change. Glob. Ecol. Biogeogr. 23:1376-1386. doi: 10.1111/geb.12228.

Bettesworth, D. J. 1972. Rattus exulans on Red Mercury Island. Tane 18:117-118. 
Blackburn, T. M., P. Cassey, R. P. Duncan, K. L. Evans, and K. J. Gaston. 2004. Avian extinction and mammalian introductions on oceanic islands. Science 305:1955-1958.

Blackburn, T. M., O. L. Petchey, P. Cassey, and K. J. Gaston. 2005. Functional diversity of mammalian predators and extinction in island birds. Ecology 86: 2916-2923.

Brescia, F. 2011. Ecology and population trends in new-Caledonian Placostylus snails (Mollusca: Gastropoda: Bulimulidae). Ph.D. diss., Massey University, New Zealand.

Capizzi, D., S. Bertolino, and A. Mortelliti. 2014. Rating the rat: Global patterns and research priorities in impacts and management of rodent pests. Mamm. Rev. 44:148162. doi: 10.1111/mam.12019.

Carlile, N., D. Priddel, and P. Honan P. 2009. The recovery programme for the Lord Howe Island Phasmid (Dryococelus australis) following its rediscovery. Ecol. Manage. Restor. 10:S124-S128.

Caut, S., J. G. Casanovas, E. Virgos, J. Lozano, G. W. Witmer, and F. Courchamp. 2007. Rats dying for mice: Modelling the competitor release effect. Austral Ecol. 32:858-868. doi: 10.1111/j.1442-9993.2007.01770.x

_ E. Angulo, and F. Courchamp. 2008. Dietary shift of an invasive predator: Rats, seabirds and sea turtles. J. Appl. Ecol. 45:428437. doi: 10.1111/j.1365-2664.2007.01438.x.

Clark, D. A. 1982. Foraging behavior of a vertebrate omnivore (Rattus rattus): Meal structure, sampling, and diet breadth. Ecology 63:763-772.

Clout, M. N. 1980. Ship rats (Rattus rattus L.) in a Pinus radiata plantation. N. Z. J. Ecol. 3:141-145.

Critical Ecosystem Partnership Fund. 2017. <https://www.cepf.net/stories/north-ameri can-coastal-plain-recognized-worlds-36thbiodiversity-hotspot $>$. Last consultation: 28/01/2019.

Daniel, M. 1973. Seasonal diet of the ship rat (Rattus rattus) in lowland forest in New Zealand. Pages 21-30 in Proceedings (New Zealand Ecological Society). JSTOR.

Delorme, Q., C. Mille, and H.Jourdan. 2016. A review of the genus Kanakia Distant, 1892 (Insecta: Hemiptera, Cicadoidea, Cicadidae) from New Caledonia. Zootaxa 4092:301338. doi: 10.11646/zootaxa.4092.3.1.

Dray, S., A.-B. Dufour, and J. Thioulouse. 2016. Package "ade4": Analysis of ecological data, exploratory and euclidean methods.

Duron, Q., E. Bourguet, H. De Meringo, A. Millon, and E. Vidal. 2017a. Invasive rats strengthen predation pressure on bird eggs in a South Pacific island rainforest. Curr. Zool. 63:583-590.

O. Garcia-Iriarte, F. Brescia, and E. Vidal. 2017b. Comparative effects of native frugivores and introduced rodents on seed germination in New-Caledonian rainforest plants. Biol. Invasions 19:351-363.

- A. B. Shiels, and E. Vidal. 2017c. Control of invasive rats on islands and priorities for future actions. Conserv. Biol. 31:761-771.

Fall, M. W., A. B. Medina, and W. B. Jackson. 1971. Feeding patterns of Rattus rattus and Rattus exulans on Eniwetok Atoll, Marshall Islands. J. Mammal. 52:69-76. doi: 10.2307/1378432.

Ferreira, S. M., G. Atkins, S. Marsh, I. Petrove, W. May, and L. Te Hira. 2001. The limitations of using kiore (Rattus exulans) diet-sampling to determine woodrose (Dactylanthus taylori, Balanophoraceae) distribution on Hauturu (Little Barrier Island), New Zealand. N.Z. J. Bot. 39:465-470. doi: 10.1080/0028825X.2001.9512749.

Gales, R. P. 1982. Age- and sex-related differences in diet selection by Rattus rattus on Stewart Island, New Zealand. N.Z. J. Zool. 9:463-466. doi: 10.1080/03014223.1982. 10423878.

Gibbs, G. W. 1998. Why are some weta (Orthoptera: Stenopelmatidae) vulnerable yet others are common? J. Insect Conserv. 2:161-166.

Gower, J. C. 1971. A general coefficient of similarity and some of its properties. Biometrics 27:857-871.

Harper, G. A., Dickinson K. J. M, and P. J. Seddon. 2005. Habitat use by three ratspecies (Rattus spp.) on Stewart Island/Rakiura, New Zealand. N. Z. J. Ecol. 29:251-260.

Harper, G. A., and D. Veitch. 2006. Population ecology of Norway rats (Rattus norvegicus) and interference competition 
with Pacific rats ( $R$. exulans) on Raoul Island, New Zealand. Wildl. Res. 33:539548. doi: 10.1071/WR05096.

- 2007. Detecting predation of a burrow-nesting seabird by two introduced predators, using stable isotopes, dietary analysis and experimental removals. Wildl. Res. 34:443-453. doi: 10.1071/WR07037. , and N. Bunbury. 2015. Invasive rats on tropical islands: Their population biology and impacts on native species. Glob. Ecol. Conserv. 3:607-627.

- M. van Dinther, J. C. Russell, and N. Bunbury. 2015. The response of black rats (Rattus rattus) to evergreen and seasonally arid habitats: Informing eradication planning on a tropical island. Biol. Conserv. 185: 66-74. doi: 10.1016/j.biocon.2014.11.044.

Innes, J. 1979. Diet and reproduction of ship rats in the northern Tararuas. N.Z. J. Ecol. 2:85-86.

IUCN. 2016. The IUCN Red List of Threatened Species. http://www.iucnred list.org/. Accessed 14 May 2016.

Jones, H. P., B. R. Tershy, E. S. Zavaleta, D. A. Croll, B. S. Keitt, M. E. Finkelstein, and G. R. Howald. 2008. Severity of the effects of invasive rats on seabirds: A global review. Conserv. Biol. 22:16-26. doi: 10.1111/ j.1523-1739.2007.00859.x.

Kumschick, S., M. Gaertner, M. Vila, F. Essl, J. M. Jeschke, P. Pyšek, A. Ricciardi, S. Bacher, T. M. Blackburn, J. T. A. Dick, T. Evans, P. E. Hulme, I. Kühn, A. Mrugała, J. Pergl, W. Rabitsch, D. M. Richardson, A. Sendek, and M. Winter. 2015. Ecological impacts of alien species: Quantification, scope, caveats, and recommendations. BioScience 65:55-63. doi: 10.1093/biosci/biu193.

Lindsey, G. D., S. M. Mosher, S. G. Fancy, and T. D. Smucker. 1999. Population structure and movements of introduced rats in an Hawaiian rainforest. Pac. Conserv. Biol. 5:94-102.

Long, J. 2003. Introduced mammals of the world, CSIRO Publishing. Canberra, Australia.

Maechler, M., P. Rousseeuw, A. Struyf, Maechler, M. Hubert, K. Hornik, M.
Studer, and P. Roudier. 2016. Package "cluster": Finding groups in data, Cluster analysis extended Rousseeuw et al. R-Cran project.

Matisoo-Smith, E., and J. H. Robins. 2004. Origins and dispersals of Pacific peoples: Evidence from mtDNA phylogenies of the Pacific rat. Proc. Natl. Acad. Sci. U.S.A. 101:9167-9172.

McQueen, S., and B. Lawrence. 2008. Diet of ship rats following a mast event in beech (Nothofagus spp.) forest. N.Z. J. Ecol. 32:214-218.

Meyer, J.-Y, and J.-F. Butaud. 2008. The impacts of rats on the endangered native flora of French Polynesia (Pacific Islands): Drivers of plant extinction or coup de grâce species? Biol. Invasions 11:1569-1585. doi: 10.1007/s10530-008-9407-y.

Mittermeier, R. A., W. R. Turner, F. W. Larsen, T. M. Brooks, and C. Gascon. 2011. Global biodiversity conservation: The critical role of hotspots. Pages 3-22 in F. E. Zachos, and J. C. Habel, eds. Biodiversity Hotspots. Springer, Berlin, Heidelberg.

Monks, J. M., A. Monks, and D. R. Towns. 2014. Correlated recovery of five lizard populations following eradication of invasive mammals. Biol. Invasions 16:167-175. doi: 10.1007/s10530-013-0511-2.

Morat, P., T. Jaffré, F. Tronchet, J. Munzinger, Y. Pillon, J.-M. Veillon, M. Chalopin, P. Birnbaum, F. Rigault, G. Dagostini, J. Tinel, and P.P. Lowry. 2012. Le référentiel taxonomique Florical et les caractéristiques de la flore vasculaire indigène de la Nouvelle-Calédonie. Adansonia 34:179221. doi: 10.5252/a2012n2a1.

Myers, N., R. A. Mittermeier, C. G. Mittermeier, G.A. Da Fonseca, and J. Kent. 2000. Biodiversity hotspots for conservation priorities. Nature 403:853-858.

Nelson, L. Jr., and F. W. Clark. 1973. Correction for sprung traps in catch/effort calculations of trapping results. J. Mammal. 54:295-298. doi: 10.2307/1378903.

O'Donnell, C. F., and J. M. Hoare. 2012. Quantifying the benefits of long-term integrated pest control for forest bird 
populations in a New Zealand temperate rainforest. N.Z. J. Ecol. 36:131-140.

Oksanen, J., F. G. Blanchet, M. Friendly et al., 2016. Package "vegan": Community Ecology Package. R-Cran project.

Pascal, M., O. Lorvelec, V. Bretagnolle, and J. Culioli. 2008. Improving the breeding success of a colonial seabird: A cost-benefit comparison of the eradication and control of its rat predator. Endanger. Species. Res. 4:267-276.

Pender, R. J., A. B. Shiels, L. Bialic-Murphy, and S. M. Mosher. 2013. Large-scale rodent control reduces pre-and post-dispersal seed predation of the endangered Hawaiian lobeliad, Cyanea superba subsp. superba (Campanulaceae). Biol. Invasions 15:213-223.

Perrin, M. R., and B. A. Curtis. 1980. Comparative morphology of the digestive system of 19 species of Southern African myomorph rodents in relation to diet and evolution. Afr. Zool. 15:22-33. doi: 10.1080/02541858.1980.11447680.

Platel, K., and K. Srinivasan. 2001. Studies on the influence of dietary spices on food transit time in experimental rats. Nutr. Res. 21:1309-1314.

Ringler, D., J. Russell, A. Jaeger, P. Pinet, M. Bastien, M. Le Corre. 2014. Invasive rat space use on tropical islands: Implications for bait broadcast. Basic Appl. Ecol. 15:179186. doi: 10.1016/j.baae.2014.01.005.

_ J. Russell, and M. Le Corre. 2015. Trophic roles of black rats and seabird impacts on tropical islands: Mesopredator release or hyperpredation? Biol. Conserv. 185:75-84. doi: 10.1016/j.biocon.2014.12. 014.

Robinet, O., J. L. Craig, and L. Chardonnet. 1998. Impact of rat species in Ouvea and Lifou (Loyalty Islands) and their consequences for conserving the endangered Ouvea Parakeet. Biol. Conserv. 86:223-232.

Rodríguez, M. M. A., and M. L. G. Herrera. 2013. Isotopic niche mirrors trophic niche in a vertebrate island invader. Oecologia 171:537-544. doi: 10.1007/s00442-0122423-8.

Rouys, S. 2008. Ecologie des rats et leur impact sur le cagou et la perruche à front rouge en forêt humide et dans le maquis de Nouvelle-Calédonie. Ph.D. diss., University of New Caledonia, Nouméa.

Ruffino, L., J. C. Russell, B. Pisanu, S. Caut, and E. Vidal. 2011. Low individual-level dietary plasticity in an island-invasive generalist forager. Popul. Ecol. 53:535-548.

Russell, J. C., B. M. Beaven, J. W. B. MacKay, D.R. Towns, and M.N. Clout. 2008. Testing island biosecurity systems for invasive rats. Wildl. Res. 35:215-221. doi: 10.1071/WR07032.

\section{- S. Caut, S. H. Anderson, and M. Lee.} 2015. Invasive rat interactions and overinvasion on a coral atoll. Biol. Conserv. 185:59-65. doi: 10.1016/j.biocon.2014.10. 001.

—, and M. N. Clout. 2004. Modelling the distribution and interaction of introduced rodents on New Zealand offshore islands. Glob. Ecol. Biogeogr. 13:497-507.

$\longrightarrow$, N.S.Sataruddin, andA.D.Heard.2014. Over-invasion by functionally equivalent invasive species. Ecology 95:2268-2276.

Shiels, A. B., and D. R. Drake. 2011. Are introduced rats (Rattus rattus) both seed predators and dispersers in Hawaii? Biol. Invasions 13:883-894. doi: 10.1007/ s10530-010-9876-7.

$\longrightarrow$, C. A. Flores, A. Khamsing, P.D. Krushelnycky, S.M. Mosher, and D.R. Drake. 2013. Dietary niche differentiation among three species of invasive rodents (Rattus rattus, R. exulans, Mus musculus). Biol. Invasions 15:1037-1048. doi: 10.1007/s10530-012-0348-0.

Simberloff, D., J.-L. Martin, P. Genovesi, V. Maris, D.A. Wardle, J. Aronson, F. Courchamp, B. Galil, E. García-Berthou, M. Pascal, P. Pyšek, R. Sousa, E. Tabacchi, and M. Vilà. 2013. Impacts of biological invasions: What's what and the way forward. Trends Ecol. Evol. 28:58-66. doi: 10.1016/j.tree.2012.07.013.

St Clair, J. J. H. 2011. The impacts of invasive rodents on island invertebrates. Biol. Conserv. 144:68-81.

Sugihara, R. T. 1997. Abundance and diets of rats in two native Hawaiian forests. Pac. Sci. 51:189-198. 
Sweetapple, P.J., and G. Nugent. 2007. Ship rat demography and diet following possum control in a mixed podocarp-hardwood forest. N.Z. J. Ecol. 31:186-201.

Tershy, B. R., K.-W.Shen, K.M.Newton, N.D. Holmes, and D.A. Croll. 2015. The importance of islands for the protection of biological and linguistic diversity. BioScience 65:592-597. doi: 10.1093/biosci/biv031.

Thibault, M., F. Brescia, H. Jourdan, and E. Vidal. 2017. Invasive rodents, an overlooked threat for skinks in a tropical island hotspot of biodiversity. N.Z. J. Ecol. 41:74-83. doi: 10.20417/nzjecol.41.9.

Towns, D. R., I. A. E. Atkinson, and C. H. Daugherty. 2006. Have the harmful effects of introduced rats on islands been exaggerated? Biol. Invasions 8:863-891.

- and K. G. Broome. 2003. From small Maria to massive Campbell: Forty years of rat eradications from New Zealand islands. N.Z. J. Zool. 30:377-398.

Tron, F. M., R. Franquet, T. H. Larsen, and J. J. Cassan. 2013. Evaluation rapide de la biodiversité du massif du Panié et des Roches de la Ouaième, province Nord, Nouvelle-Calédonie., Conservation International. Arlington, VA, USA.

Walsh, J. C., O. Venter, J. E. M. Watson, R.A. Fuller, T.M. Blackburn, H.P. Possingham. 2012a. Exotic species richness and native species endemism increase the impact of exotic species on islands. Glob. Ecol. Biogeogr. 21:841-850. doi: 10.1111/ j.1466-8238.2011.00724.x.
, K. A. Wilson, J. Benshemesh, and H. P. Possingham. 2012b. Unexpected outcomes of invasive predator control: The importance of evaluating conservation management actions. Anim. Conserv. 15:319-328. doi: 10.1111/j.1469-1795.2012. 00537.x.

Watts, C. H., D. P. Armstrong, J. Innes, and D. Thornburrow. 2011. Dramatic increases in weta (Orthoptera) following mammal eradication on MaungatautariEvidence from pitfalls and tracking tunnels. N.Z. J. Ecol. 35:261-272.

Williams, P. A., B. J. Karl, P. Bannister, and W. G. Lee. 2000. Small mammals as potential seed dispersers in New Zealand. Austral. Ecol. 25:523-532.

Yabe, T., T. Hashimoto, M. Takiguchi, M. Aoki, and K. Kawakami. 2009. Seabirds in the stomach contents of black rats Rattus rattus on Higashijima, the Ogasawara (Bonin) Islands, Japan. Mar. Ornithol. 37:293-295.

Yom-Tov, Y., S. Yom-Tov, and Moller H. 1999. Competition, coexistence, and adaptation amongst rodent invaders to Pacific and New Zealand islands. J. Biogeogr. 26:947-958.

Zarzoso-Lacoste D., E. Bonnaud, E. Corse, A. Gilles, E. Meglecz, C. Costedoat, A. Gouni, and E. Vidal. 2016. Improving morphological diet studies with molecular ecology: an application for invasive mammal predation on island birds. Biol. Conserv. 193:134-142. 